Annals of Warsaw University of Life Sciences - SGGW

Land Reclamation No 44 (2), 2012: 111-119

(Ann. Warsaw Univ. of Life Sci. - SGGW, Land Reclam. 44 (2), 2012)

\title{
Assessment of the state of water quality of the Dzierzgon Lake using chemical and biological indicators
}

\author{
MAGDALENA FRAK, ANNA BARYŁA \\ Department of Environmental Improvement, Warsaw University of Life Sciences - SGGW
}

\begin{abstract}
Assessment of the state of water quality of the Dzierzgon Lake using chemical and biological indicators. The paper presents an assessment of the state of water pollution of the Dzierzgon Lake based on bacteriological indicators. Water samples were taken at two measurement points in four study periods in July and August 2011 and 2012. A total number of psychrophilic bacteria and MPN of faecal coliforms were determined. In addition, selected chemical parameters of water quality were analyzed, including total organic carbon and total nitrogen. The results were compared with those obtained by the Provincial Inspectorate for Environmental Protection in 1998 and 2004, and by Rychlik in 2009. It can be concluded that the sanitary condition of the Dzierzgon Lake is satisfactory.
\end{abstract}

Key words: Dzierzgoń Lake, water quality, bacteriological contamination, sanitary state.

\section{INTRODUCTION}

The rapid development of civilization, technological progress, industrial development, urbanization and motorization, carries many risks for the environment. One of them is an increasing degradation of lake ecosystems, which are more susceptible to contamination than the flowing waters (Traczykowski et al. 2009). Water bodies are an important element of the landscape. By delaying water outflow they perform the function of retention reservoirs as well they are the habitat of many, often valuable species of flora and fauna. They are used by humans mainly for outdoor recreation or swimming in the summer season.

Regrettably, aquatic ecosystems are exceptionally sensitive to external conditions. Pollution from human activity can cause changes in the physico-chemical properties and eutrophication of water resulting in the deterioration of light conditions, depletion of oxygen resources, changes in the $\mathrm{pH}$ value and redox potential, increase in the amount of organic matter, as well as changes in water colour and odour. Eutrophication often leads to the formation of cyanobacterial blooms, which may have serious economic and social impacts, such as limited use of water. In addition, cyanobacterial blooms and some contaminants may cause water toxicity (Kononen 2001; Kajak 1998). Therefore, it is important to control the hydrological status of reservoirs and the degree of their silting, as well as water quality to ensure the safety of the users.

The effectiveness of the protection of lakes from contamination depends, to a large extent, on the type of pollution sources. In the case of point sources, the best form of protection is to reduce sewage discharge into the lakes. However, non-point source pollution of both the atmospheric and agricultural origin may be a problem (Kajak 1998). There- 
fore, proper spatial planning for the area around reservoirs and appropriate water management in the basin are of key importance. The paper discusses the longterm changes in selected physico-chemical and hydrobiological parameters of water quality of the Dzierzgoń Lake.

\section{Dzierzgoń Lake characteristics}

Administratively, the Dzierzgon Lake (Fig. 1) is located in the municipality of Prabuty, Kwidzyn County, Pomeranian Province. Geographically, it lies in the western part of the Iława Lakeland, East-Pomeranian Lakeland, in the Liwa River Valley, in the Liwa-Nogat-Baltic basin. According to Marszelewski (2000) the Ilawa Lakeland is the region with the largest number of the most polluted lakes. Literature provides different data on the surface area of the Dzierzgon Lake. According to the Inland Fisherie Institute in Olsztyn from 1952 (Rychlik 2010) its area is 787.9 ha, according to the extract from the land register as of 27 September 2001, it is 899.03 ha, while to Choiński (2008) it is 837.5 ha and is ranked $37^{\text {th }}$ among the lakes in Poland. The maximum depth of the lake is $15 \mathrm{~m}$ (with an average of $6.4 \mathrm{~m}$ ), the coastline length $-20,675 \mathrm{~m}$, the capacity - ca $51 \times 10^{6} \mathrm{~m}^{3}$, the maximum length $6935 \mathrm{~m}$, the effective length $-5750 \mathrm{~m}$, the maximum width $-1955 \mathrm{~m}$, the effective width $-2100 \mathrm{~m}$, the total catchment area $-319.9 \mathrm{~km}^{2}$.

The Dzierzgoń Lake has the shape of a trough, surrounded in the east by ground moraine hills with a height of $105 \mathrm{~m}$ a.s.1., and in the southwest - by the accumulation moraine. In the west, there are glacial tills separated by fluvioglacial sands. The lake was formed during the last Pomeranian phase of the Baltic glaciation. The mean water level is $81.5 \mathrm{~m}$ a.s.1. (Choiński 2008). There are three islands on the lake, with a total area of 5.9 ha and coastline length of $1675 \mathrm{~m}$ (Regional Inspectorate for Environment Protection in Gdańsk 2004).

The Liwa River flows through the southern part of the lake, so it is classi-



FIGURE 1. The Dzierzgoń Lake (http://www.prabuty.pl) 
fied as a flow-through lake. According to Kubiak et al. (2006) this characteristic has an adverse effect on the lake, which is rather shallow and the catchment area is intensively used for agriculture and tourism.

The direct catchment area of the Dzierzgoń Lake is mainly land used for agricultural purposes. Nearly $50 \%$ of land covered by the spatial development plan are open areas. These are areas designated for forestry, management of green areas for any purpose, including recreational development within the existing agricultural habitats, such as technical infrastructure buildings, unless they are harmful to the environment (Local Municipal Plan of Spatial Development of Prabuty).

On the southern bank of the lake there is a swimming area neighbouring with summer houses and a recreation centre. Currently, a new development plan for the area surrounding the lake is being prepared, providing for the growth of tourism in the region.

\section{MATERIALS AND METHODS}

Water samples for analysis were collected on 2 and 29 August 2011, and 19 July 2012 and 8 August 2012 at two measurement points (one control point and a city beach - see Fig. 2) on the Dzierzgoń Lake, corresponding one of five control points designated and monitored by Regional Inspectorate for Environment Protection in Gdańsk in the years 1998 and 2004, and corresponding to the sampling points in the studies conducted by Rychlik in 2009.

Collected water samples were analysed for the selected chemical para-



FIGURE 2. Measuring points of the Dzierzgon Lake

meters of water quality. The concentration of TOC (total organic carbon in $\mathrm{mg} \cdot \mathrm{l}^{-1}$ ) and $\mathrm{N}$ (total nitrogen in $\mathrm{mg} \cdot \mathrm{l}^{-1}$ ) was determined by the high temperature method (automatic flow analyzer SCALAR Formacs HT/TN) according to ISO 8245 EPA 415.1. The levels of nitrite, nitrate, ammonia and chlorides were determined by the liquid chromatography technique using a Dionex ICS-1000 apparatus (samples were subjected to filtration prior to measurement to remove suspended solids). Measurements of dissolved oxygen (in mg $\mathrm{O}_{2} \cdot \mathrm{l}^{-1}$ ) were performed by the Winkler method. Furthermore, the fermentation method was used to estimate the most probable number of Escherichia coli according to PN77/C$-04615 / 07$ (the result was given as MPN per $100 \mathrm{~cm}^{3}$ ). The result was confirmed by the plate method using Endo medium 
(Zmysłowska 2000; Duszkiewicz-Reinhard et al. 2003) in cultures incubated at the temperature of $44^{\circ} \mathrm{C}$. Moreover, the taxonomic structure composition of phytoplankton communities was analysed, with special reference to the presence of cyanobacteria. The taxa of organisms found in the samples were determined and dominants were separated. The classification of organisms was made according to Huber-Pestalozzi et al. (1983).

\section{RESULTS AND DISCUSSION}

Water samples from the swimming area of the Dzierzgon Lake were analysed for surface phytoplankton biodiversity. Cyanobacteria (Cyanophyta) Woronchinia naegeliana and Microcystis aeruginosa (Fig. 3) were the dominant organisms forming blooms during the summer. The studies conducted by Rychlik in 2009 showed the presence of numerous blue-green algae of the genera Woronchinia and Microcystis producing hepatotoxins. Moreover, the presence of Chlorococcus as well as a few neurotoxin producing Anabena spiroides and Planktothrix were detected.

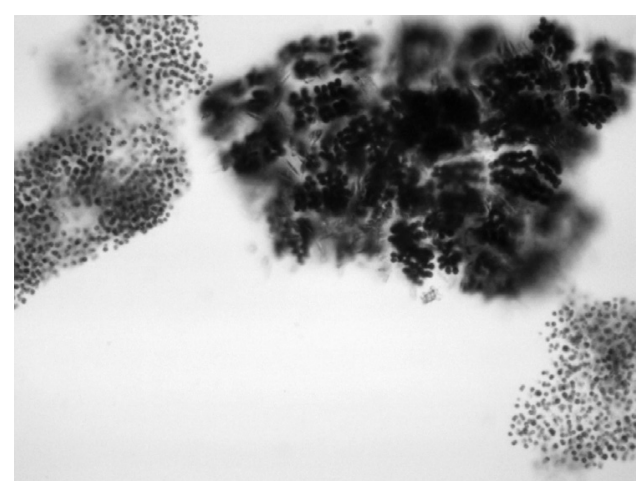

In the collected water samples, no dominants were found among the identified algae (except for the blue-green algae). A high number of green algae can be linked with the seasonality of their occurrence. These were, i.a. Pediastrum duplex, Coenococcus planctonicus, Coleastrum astroideum, Sphaerocystis and Tetraedron trigonum. The diatoms identified in the tested water samples included Navicula, Asterionella, Stephanodiscus, as well as a few flagellates (Euglenoids), and single Trachelomonas. Numerous Ceratium hirudinella and equally numerous Peridinium sp. were identified. Their biodiversity was comparable to that of phytoplankton identified by Rychlik in 2009 (Rychlik 2010), and by the Regional Inspectorate for Environment Protection in Gdańsk in 2004. The water samples taken in 2004 contained diatoms Stephanodiscus rotula, Asterionella formosa, cyanobacteria Microcystis aeruginosa and protozoa Flagellata apochromotica and many others. Flagellata apochromatica was the dominant zooplankton species (accounting for more than 90 percent in all sampling points both in the spring and in the summer). Chilodonella uncinata,

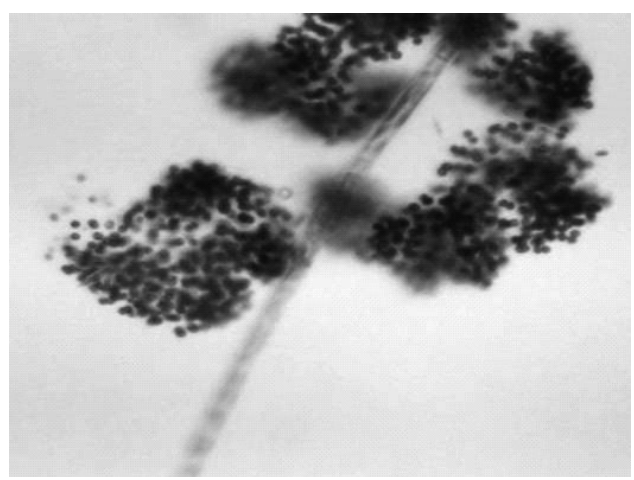

FIGURE 3. Woronchinia and Microcystis $($ zoom ×600) 
Amoeba proteus, Codonella cratera occurred sporadically.

Only species that produce aerotopes are capable of forming blooms in the surface water, as in the case of the Dzierzgon Lake. These structures are composed of numerous cylindrical gas vacuoles (up to 10,000 per cell). They enable vertical movements and existence of cyanobacteria in a water column in the optimal light conditions and nutrient concentrations. Aerotopes occur in filamentous species of the genus Nodularia, Aphanizomenon, Dolichospermum (Anabaena), Planktothrix and Cylindrospermopsis, as well as colonial cyanobacteria of the genus Microcystis and Woronchinia (Błaszczyk et al. 2010).

An increase in the concentrations of biogenic substances in the reservoir promotes the appearance of phytoplankton in large numbers. The dependence of the appearance of cyanobacterial blooms on the level of eutrophication is well documented (Paerl 1996). The low value of the ratio of total nitrogen to total phosphorus $(\mathrm{N} / \mathrm{P}<16)$ was considered significant, although it was not the only factor favouring the growth of cyanobacteria. The low value of N/P often indicates a deficit of nitrogen in the water, which contributes to greater competitiveness of these species of cyanobacteria which contain heterocysts and demonstrate the ability of fixing atmospheric nitrogen.

Cyanobacteria produce such a large number of different toxins that they can be considered the main source of this type of compounds both in inland and marine waters. Numerous studies show that hepato- and neurotoxins are the most common group of toxins produced by cyanobacteria. The mass occurrence of cyanobacteria adversely affects the functioning of aquatic environments. This phenomenon can also lower the quality of utilitarian waters. Cyanobacteria are in fact the producers of compounds having a negative effect on human and animal organisms (Kuiper-Goodman et al. 1999).

Hepatotoxins are readily absorbed from the gastrointestinal tract into the bloodstream, where they are quickly taken up by liver cells. Animal organisms subjected to their action, die in a characteristic lethargy, preceded by a strong congestion and swelling of the liver. The most dangerous for a man are neurotoxins. They damage the central and peripheral nervous system. The main symptoms of poisoning are muscle tremors, dizziness, laboured breathing and convulsions. Despite the frequent occurrence of cyanobacterial blooms in Poland's waters, poisoning caused by neurotoxins is rarely recorded (Frąk et al. 2012).

Tests conducted for the presence of faecal coliforms showed no exceedance of the permissible limit (Table 1), while the values for the tributary of the Liwa River reported by Rychlik in 2009 were higher than for the lake. Parameter values at the measurement points, where the presence of faecal coliforms was detected, were higher (amounting to $240 \mathrm{MPN}$ per $100 \mathrm{ml}$ ) than the desirable limit of up to 100 MPN per $100 \mathrm{ml}$. However, they do not exceed the limit values which should be lower than 1000 MPN per $100 \mathrm{ml}$ for the swimming area. The increased number of Escherichia coli indicates the influx of contaminants of faecal origin. However, the obtained results (240 MPN per $100 \mathrm{ml}$ ) point to the surface runoff from the catchment area or the discharge 
of treated wastewater into the Liwa River as the source of water contamination. The presence of Escherichia coli indicates recent faecal contamination of water, therefore, the suggestion that the exceedance of bacteriological limits is the result of the earlier contamination of the environment finds no justification. The analysis of chemical parameters of water quality of the Dzierzgon Lake showed a slight improvement in water quality in the years between 1998 and 2012 .

In the study periods, chloride concentrations were found to be low, ranging from $8.84 \mathrm{mg} \mathrm{Cl} \cdot \mathrm{l}^{-1}$ in 2009 to $26.30 \mathrm{mg}$ $\mathrm{Cl} \cdot \mathrm{l}^{-1}$ in 2004 (Table 1). Their concentrations in the tested water samples indicate a lack of sewage discharge into the reservoir at a level of anthropogenic pollution (Hermanowicz et al. 1999, Ligęza and Wilk-Woźniak 2006), which is closely connected with the absence of built-up areas near the lake. Regrettably, the $\mathrm{pH}$ values $(7.85-9.0)$ point to the presence of alkaline ions. The concentration of dissolved organic carbon was determined at a level of $20.23 \mathrm{mg} \mathrm{C} \cdot 1^{-1}$, These results classify reservoir waters as contaminated.

High concentrations of dissolved organic carbon DOC in 2011 year and low concentrations of detected nitrates (including ammonia - less than $0.06 \mathrm{mg} \cdot 1^{-1}$, and nitrite $-0.01 \mathrm{mg} \cdot 1^{-1}$, in all samples) in relation to total nitrogen indicate strong biodegradation processes. Intensive proteolytic processes, ammonification, and nitrification lead to the production of ammonia and nitrates. The produced mineral nitrogen is absorbed by aquatic plants, such as macrophytes and phytoplankton growing robustly in the reservoirs during the warm months (Burchard 1994, Frąk 2006). Moreover, with the high contamination of water by organic carbon compounds, nitrogen produced during their mineralization, is taken up by microorganisms without the release of free ammonia to the environment (Ligęza and Wilk-Woźniak 2006, Piechowiak and Kraska 2008). A large number of psychrophilic bacteria

TABLE 1 . The values of basic parameters of water quality of the Dzierzgon Lake

\begin{tabular}{|l|c|c|c|c|c|c|}
\hline Parameters & Unit & 1998 & 2004 & 2009 & 2011 & 2012 \\
\hline Phosphate $\mathrm{P}$ & $\mathrm{mg} \cdot \mathrm{dm}^{-3}$ & 0.04 & $0.27-0.79$ & 0.94 & n.d & $0.012-0.081$ \\
\hline Nitrogen $\mathrm{N}$ & $\mathrm{mg} \cdot \mathrm{dm}^{-3}$ & n.d. & n.d. & n.d. & 0.63 & n.d. \\
\hline Ammonium $\mathrm{NH}_{4}$ & $\mathrm{mg} \cdot \mathrm{dm}^{-3}$ & $0.25-0.33$ & $0.04-0.82$ & 0.16 & 0.03 & $0.10 ;<0.1$ \\
\hline Nitrite $\mathrm{NO}_{2}$ & $\mathrm{mg} \cdot \mathrm{dm}^{-3}$ & n.d. & n.d. & n.d. & 0.01 & 0.01 \\
\hline Nitrate $\mathrm{NO}_{3}$ & $\mathrm{mg} \cdot \mathrm{dm}^{-3}$ & n.d. & n.d. & 0.60 & 1.97 & 0.70 \\
\hline Chloride $\mathrm{Cl}$ & $\mathrm{mg} \cdot \mathrm{dm}^{-3}$ & $22.00-24.00$ & $16.00-26.30$ & $8.84-10.90$ & 10.10 & n.d. \\
\hline $\begin{array}{l}\text { Dissolved inorga- } \\
\text { nic carbon DIC }\end{array}$ & $\mathrm{mg} \cdot \mathrm{dm}^{-3}$ & n.d. & n.d. & n.d & 57.56 & n.d. \\
\hline $\begin{array}{l}\text { Dissolved organic } \\
\text { carbon DOC }\end{array}$ & $\mathrm{mg} \cdot \mathrm{dm}^{-3}$ & n.d. & n.d. & n.d. & 20.23 & n.d. \\
\hline Escherichia coli & $\begin{array}{c}\mathrm{MPN} \cdot 100 \\
\mathrm{~cm}^{-3}\end{array}$ & 50 & $4-50$ & 240 & $6-23$ & $6-23$ \\
\hline pH & & $8.10-8.80$ & $8.70-9.00$ & $7.85-8.05$ & n.d. & $6.64-8.33$ \\
\hline
\end{tabular}


occurring in the discussed water reservoirs confirms high nutrient availability. Elevated concentrations of dissolved inorganic carbon (DIC) are mainly due to surface runoff and an increased outflow of this form of carbon from the catchment area.

The analysis of oxygen measurements (Regional Inspectorate for Environment Protection in Gdańsk 2004) performed at different depths on individual dates showed that changes in oxygen levels were insignificant. It can be concluded that water oxygen stratification in the Dzierzgoń Lake does not occur. The results showed the formation of anaerobic zones in the deepest point of the lake, as well as in its southern part.

\section{CONCLUSIONS}

1. Water samples from the swimming area of the Dzierzgon Lake showed that Cyanobacteria (Cyanophyta) Woronchinia naegeliana and Microcystis aeruginosa were the dominant organisms forming water blooms during the summer.

2. Tests conducted for the presence of faecal coliforms showed no exceedance of the permissible limit.

3. High concentrations of dissolved organic carbon (DOC) and low concentrations of detected nitrates (including ammonia - less than $0.06 \mathrm{mg} \cdot \mathrm{l}^{-1}$, and nitrite $-0.01 \mathrm{mg} \cdot \mathrm{l}^{-1}$, in all samples) in relation to total nitrogen indicate strong biodegradation processes. Elevated concentrations of dissolved inorganic carbon (DIC) are mainly due to surface runoff and increased outflow of this form of carbon from the catchment area.

4. Concentrations of phosphates in the water (in 2009) continue to be high, which accounts for the effect of changes in the management of the direct catchment area on the status of the reservoir and its progressive degradation.

A hypothesis can be formulated that contaminants enter the reservoir with the surface runoff from nearby agricultural land or, periodically, with rampant domestic sewage discharges from adjacent summer houses. It is recommended that protective green belts (including high green belts), acting as a barrier to contaminant migration be taken into account in development plans for the direct catchment area of the Dzierzgon Lake. Also, the control of sewage discharges from the local, seasonally used summer houses should be more stringent.

\section{REFERENCES}

BŁASZCZYK A., TORUŃSKA A., KOBOS J., BROWARCZYK-MATUSIAK G., MAZUR-MARZEC H. 2010: Ekologia toksycznych sinic. Kosmos Vol. 59, 1-2 (286-287), 173-198.

BURCHARD L. 1994: Dzisiejsze możliwości biologicznej oceny hypertrofii i politrofii w akwenie. In: M. Zalewski [Ed.]. Zintegrowana strategia ochrony $i$ zagospodarowania ekosystemów wodnych. Biblioteka Monitoringu Środowiska, 61-66.

CHOIŃSKI A. 2008: Limnologia fizyczna Polski. Wyd. Naukowe Uniwersytetu Adama Mickiewicza w Poznaniu, Poznań. [In Polish]. 
DUSZKIEWICZ-REINHARD W., GRZYBOWSKI R., SOBCZAK E. 2003: Teoria $i$ ćwiczenia z mikrobiologii ogólnej $i$ technicznej. Wyd. SGGW, Warszawa [In Polish].

FRĄK M. 2006: Analiza różnorodności fitoplanktonu jako wskaźnika jakości rzek nizinnych. Zesz. Problem. Postęp. Nauk Roln. 515, 81-88 [In Polish].

FRĄK M., KARDEL I., JANKIEWICZ U. 2012: Occurrence of nitrogen cycle bacteria in the Biebrza River. Ann. Warsaw Univ. Life Sci. - SGGW, Land Reclam. 44 (1), 55-62 [In Polish].

HERMANOWICZ W., DOJLIDO J., DOŻAŃSKA W., KOZIOROWSKI B. 1999: Fizykochemiczne badanie wody i ścieków. Arkady, Warszawa [In Polish].

HUBER-PESTALOZZI G., KOMAREK J., FOTT B. 1983: Das Phytoplankton des Süsswassers - Systematik and Biologie. Schweizerbart'sche Verlagsbuchhandlung, Stuttgart.

KAJAK Z. 1998: Hydrobiologia - Limnologia. Ekosystemy wód śródladowych. Wyd. Nauk. PWN, Warszawa [In Polish].

KONONEN K. 2001: Eutrophication, harmful algal blooms and species diversity in phytoplankton communities: examples from the Baltic Sea. Ambio 30, 184-189.

KUBIAK J., TÓRZ A., NĘDZAREK A. Hydrochemical conditions, susceptibility to degradation, trop hic state and rate of eutrophication In Bydgoszcz Lake. Acta Scientarum Polonorum Piscaria Vol. 5, 1, 73-89.

KUIPER-GOODMAN T., FALCONER I., FITZGERALD J., 1999: Human heat aspect. in: Toxic cyanobacteria in water: a guide to their public health consequences, monitoring and management. eds: I. Chorus, J. Bartman, WHO Publ. E.\&F. N.Spon., London-New York, 41-111.

LIGĘZA S., WILK-WOŹNIAK E. 2006: Jakość wody w zbiornikach o różnym nasileniu antropopresji a strategie życiowe glonów planktonowych. Zesz. Problem. Postęp. Nauk Roln. 515, 251-260 [In Polish].
Local Municipal Plan of Spatial Development of Prabuty Resolution of Prabuty City Counsil XXIV/161/97, 31.05.1997.

MARSZELEWSKI W. 2000: Naturalne i antropogeniczne przemiany jezior. Próba podziału jezior najsilniej zanieczyszczonych. IV $^{\text {th }}$ Limnologic Conference Zalesie k. Olsztyna [In Polish].

PAERL H. 1996: A comparison of cyanobacterial bloom dynamics in freshwater, estuarine and marine environments. Phycologia 35, 25-35.

PIECHOWIAK M., KRASKA M. 2008: The effect of humic substances on nitrogen cycle bacteria. Ocean. Hydrobiol. Stud. XXXVII, Supl. 1, 99-108.

Regional Inspectorate for Environment Protection in Gdańsk (WIOS Gdańsk) 2004: Wyniki badań fizykochemicznych i bakteriologicznych z 3 punktów pomiarowych na Jeziorze Dzierzgoń z lat 1998-2004. Wyniki pomiarów tlenu z 3 punktów pomiarowych na J. Dzierzgoń [In Polish].

RYCHLIK J. 2010: Analiza wpływu zagospodarowania zlewni bezpośredniej na jakość wód jeziora Dzierzgoń. (post-graduate disertation SGGW, typework) [In Polish].

TRACZYKOWSKI A., BERLEĆ K., RZEPCZYK B. 2009: Jakość wód powierzchniowych po rekultywacji na przyktadzie Jeziora Gtęboczek. Środkowo-Pomorskie Towarzystwo Naukowe Ochrony Środowiska Vol. 11, 507-511 [In Polish].

ZMYSŁOWSKA I. 2000: Mikrobiologia ogólna i środowiskowa. Wyd. Uniwersytetu Warmińsko-Mazurskiego, Olsztyn [In Polish]

\section{Acknowledgements}

The used equipment in examinations is the part of equipment of Water Center, Research and Didactic Laboratory of the Faculty of Civil and Environmental Engineering, Warsaw University of Life Sciences - SGGW. 
Streszczenie: Stan zanieczyszczenia wód jeziora Dzierzgoń na podstawie wskaźników chemicznych $i$ bakteriologicznych. W artykule zbadano stan zanieczyszczenia wód jeziora Dzierzgoń na podstawie wskaźników bakteriologicznych. Pobrano próbki wody $\mathrm{w}$ dwóch punktach pomiarowych $w$ czterech terminach badawczych, tj. w lipcu i sierpniu w latach 2011 i 2012. Oznaczono ogólną liczbę bakterii psychrofilnych oraz NPL bakterii coli typu kałowego. Ponadto zanalizowano wybrane wskaźniki chemicznej jakości wody, m.in. ogólną zawartość węgla organicznego, azotu całkowitego i fosforu fosforanowego. Uzyskane wyniki porównano z wynikami uzyskanymi przez WIOŚ w latach 1998 i 2004, oraz wynikami badań uzyskanymi przez Rychlik w 2009 roku. Można stwierdzić, że stan sanitarny jeziora jest zadawalający.

Słowa kluczowe: jezioro Dzierzgoń, jakości wód, zanieczyszczenia bakteriologiczne, zanieczyszczenia sanitarne

MS. received November 2012

\section{Author's address:}

Magdalena Frąk

Katedra Kształtowania Środowiska

Szkoła Główna Gospodarstwa Wiejskiego

ul. Nowoursynowska 159, 02-787 Warszawa

Poland

e-mail: magdalena_frak@sggw.pl 